\title{
THE CHANGE OF DEMOGRAFIC INDICATORS, THE LEGAL FORM OF THE OWNERSHIP, THE OWNER SHARE OF A PHARMACIST IN THE CAPITAL AND ECONOMIC SITUATION IN THE COMMUNITY PHARMACIES RESULTING FROM GLOBALIZATION
}

\author{
Ivona Malovecká, Daniela Mináriková, Viliam Foltán \\ Comenius University in Bratislava, Slovak Republic.E-mail: ivonamalovecka@gmail.com, \\ malovecka@fpharm.uniba.sk
}

The aim of this paper was to determine a demographic situation, the legal form of the ownership, the owner share of a pharmacist in the capital and the economic situation in the community pharmacies of Slovakia. The number of community pharmacies constantly increases (1540 pharmacies in 2012). The legal forms of the ownership in community pharmacies were limited companies (73.6\%), a sole proprietor - pharmacists (23.9\%), and Joint Stock Companies (1.3\%); in the community pharmacy branches there were also limited companies (73.4\%), a sole proprietor - pharmacists (26\%), Joint Stock Companies (1\%). The owner share of the pharmacist in the capital of public pharmacies was 50.4\%, and in the community pharmacy branches it was 66\%. The financial analysis for the period of 2007-2012 showed decline in Return on Sales (in 2012 to $1.98 \%$ ), decrease of liquidity due to the Current Ratio (in 2012 to 1.87) and the Quick Ratio (in 2012 to 1.08), decrease in the Average Collection Period (in 2012 to 53.8 days), a slight increase in the Average Inventory Period (in 2012 to 36.5 days) and the increased Average Payment Period (in 2012 to 86.3 days).

Key words: community pharmacy, demographical analysis, legal form of the pharmaceutical care provider, owner's share on the capital, financial analysis, profitability, liquidity, efficiency.

Introduction. Public pharmacies are excellent medical facilities having the largest number of contacts with patients [1]. They are the facilities of the first and last contact with the healthcare system for the patient. Public pharmacies are unique and easily accessible places in the healthcare system with a high proficiency in provision of pharmaceutical care and the highly qualified medical staff $[2,3]$. A community pharmacy provides citizens with pharmaceutical care and runs its healthcare business at the market with state regulatory interventions $[4,5]$. These restrictions affect its stability and because of that it has to be constantly

Ivona Malovecká - PharmDr. Ing., Department of Organisation and Management in Pharmacy, Faculty of Pharmacy, Comenius University in Bratislava (Slovak Republic) monitored $[6,7]$. The convenient way of monitoring the financial situation of a community pharmacy is financial analysis and its outcomes such as profitability, liquidity, debt and productivity ratios $[8,9,10,11]$.

Experimental part. Methods. The data about the demographic situation were obtained from Health Yearbooks [12] and the Eurostat European commission database from 2007 2012 [13]. The data concerning the legal status were drawn from self-governing regions, the database of the Trade Register of the Slovak Republic [14], the Commercial Register of the Slovak Republic [15] and the databases of the Statistical Office of the Slovak Republic by the date of 31.12. 2012 [16]. Based on these data a set of databases of community pharmacies and the community pharmacy branches 
DEMOGRAPHIC ANALYSIS OF COMMUNITY PHARMACIES AND COMMUNITY PHARMACIES BRANCHES IN THE SLOVAK REPUBLIC WITHIN THE PERIOD OF 2007-2012

\begin{tabular}{|c|c|c|c|c|c|c|}
\hline Years & $\begin{array}{c}\text { Community } \\
\text { pharmacy }\end{array}$ & $\begin{array}{c}\text { Community } \\
\text { pharmacy } \\
\text { branch }\end{array}$ & $\begin{array}{c}\text { Community } \\
\text { pharmacy } \\
\text { established as a } \\
\text { training point }\end{array}$ & $\begin{array}{c}\text { Total } \\
\text { providers of } \\
\text { pharmaceutical } \\
\text { care }\end{array}$ & $\begin{array}{c}\text { Number of } \\
\text { inhabitants }\end{array}$ & $\begin{array}{c}\text { Number of } \\
\text { inhabitants per } \\
\text { a community } \\
\text { pharmacy }\end{array}$ \\
\hline 2007 & 1382 & 89 & 4 & 1475 & 5400998 & 3662 \\
\hline 2008 & 1177 & 101 & 3 & 1281 & 5412254 & 4225 \\
\hline 2009 & 1281 & 66 & 2 & 1349 & 5424925 & 4021 \\
\hline 2010 & 1420 & 71 & 2 & 1493 & 5435273 & 3641 \\
\hline 2011 & 1468 & 55 & 1 & 1524 & 5404322 & 3546 \\
\hline 2012 & 1463 & 76 & 1 & 1540 & 5410836 & 3514 \\
\hline
\end{tabular}

in the Slovak Republic has been compiled, and it is included:

1. Demographic analysis within the period of 2007-2012.

2. Analysis of the legal form of the ownership in community pharmacies and community pharmacy branches by the date of 31.12.2012.

3 . Analysis of the owner share of a pharmacist in the capital of the community pharmacy and community pharmacy branches by the date of 31.12.2012.

4 . Financial analysis of the community pharmacies (54) and the community pharmacy branches (7) within the period of 2007-2012 by profitability, liquidity and efficiency parameters.

Then the data were summarized in tables and analysed using the Microsoft Excel 2010 software and freely available extensions.

Results. For the purposes of the given work we understand the entity providing pharmaceutical care in the community pharmacy or in the community pharmacy branches under the term "a provider of pharmaceutical care". Pharmaceutical care is provided also in other healthcare facilities excluded from the analysis.

1. Demographic analysis of community pharmacies and community pharmacy branches in the Slovak Republic within the period of 2007-2012

Demographical analysis revealed the increasing number of healthcare facilities, stagnant number of inhabitants and decrease in number of inhabitants per a community pharmacy.

2. Analysis of the legal form of the ownership in community pharmacies and community pharmacy branches

The analysis of the legal form of the ownership in community pharmacies and commu- nity pharmacy branches was made by the date of 31.12.2012 and included 1540 community pharmacies and community pharmacy branches. The analysis in community pharmacies revealed that the most common legal form of the ownership was legal entity - company limited. In this legal form $73.6 \%$ of community pharmacies was in business. In the legal form of sole proprietor - a pharmacist $23.9 \%$ of community pharmacies worked, and the form of the ownership through Joint Stock Company was used by $1.3 \%$ of community pharmacies. Other legal forms (cooperative, limited partnership, general partnership, etc.) accounted for the remaining $1.2 \%$ of community pharmacies. The analysis in community pharmacy branches showed that again the most common legal form of the ownership was legal entity - company limited. In this legal form $73.0 \%$ of community pharmacy branches was in business. In the legal form of sole proprietor - a pharmacist $26.0 \%$ of community pharmacy branches worked, and the form of the ownership through Joint Stock Company was used by $1.0 \%$ of community pharmacy branches. Other legal forms (cooperative, limited partnership, general partnership, etc.) accounted for the remaining $1.2 \%$ of community pharmacy branches.

3. Analysis of the owner share of a pharmacist in the capital of community pharmacies and community pharmacy branches

The analysis of the owner share in the capital of the pharmaceutical care provider in community pharmacies and in the branches of community pharmacies was made by the date of 31.12.2012 and included 1540 community pharmacies and community pharmacy branches. The analysis in the group of community 
Inhabitants per a pharmacy in Europe in 2012

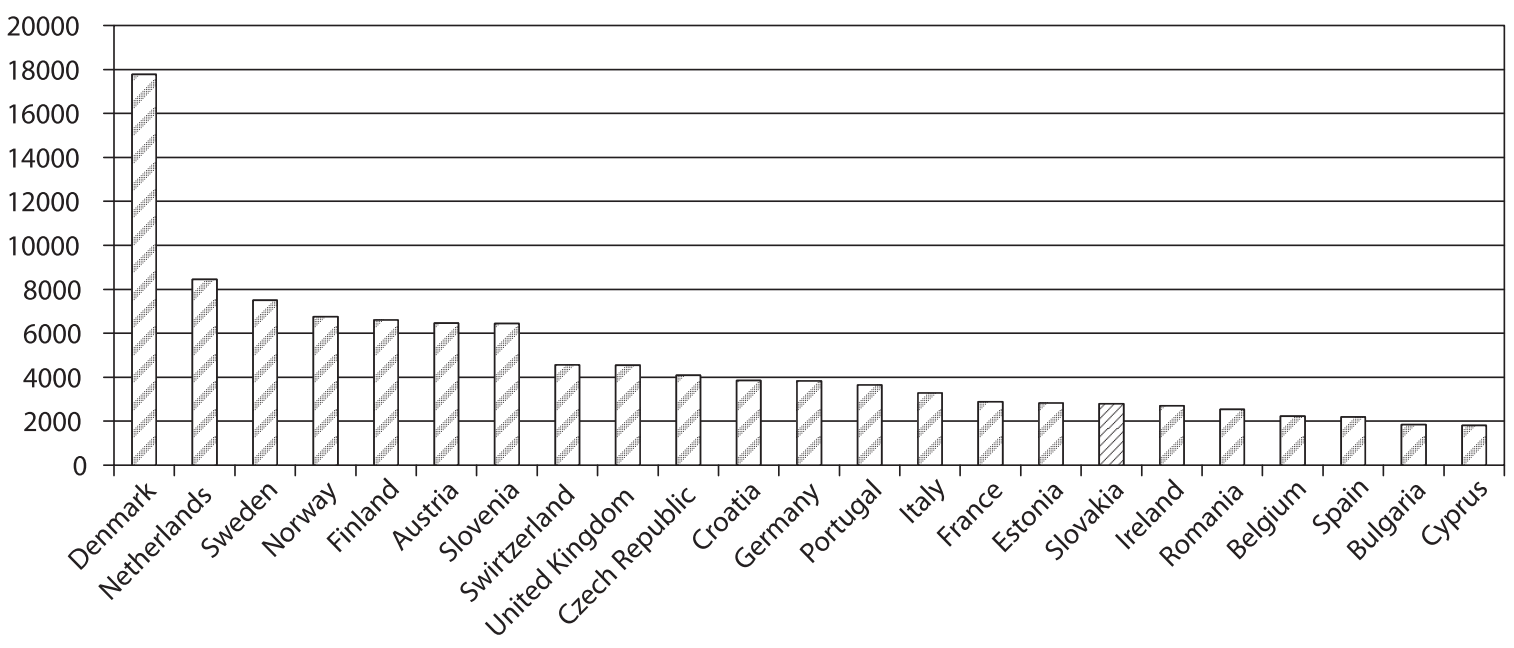

Fig. Inhabitants per a pharmacy in Europe in 2012 [19, 20] (the own analysis from the sources mentioned)

pharmacies showed that $50.4 \%$ of the owner share in the capital was in the hands of pharmacists, either in the form of sole proprietor a pharmacist or legal entity - company limited. Further analysis in the group of community pharmacy branches showed that $66.0 \%$ of the owner share in the capital was in the hands of pharmacists, also either in the form of sole proprietor - a pharmacist or legal entity - company limited. This implies that the owner share in the capital in the community pharmacy branches was $15.6 \%$ more than the owner share in capital of the community pharmacies.

4. Financial analysis of community pharmacies and community pharmacy branches within the period of 2007-2012

Financial analysis was based on profitability, liquidity and efficiency analysis at $61 \mathrm{com}$ munity pharmacies and community pharmacy branches.

\section{Profitability Analysis \\ Return on Sales}

The Profitability Analysis of community pharmacies (54) and community pharmacy branches (7) was carried out by the parameter Return on Sales (RS). RS in the reporting time was in two periods. The first period was within 2007-2009, in which RS showed a downward trend (RS $2007=1.65 \%$, RS $2008=1.53 \%$, RS $2009=1.54 \%$ ). In the second period within 2010-2012, RS also showed a downward trend (RS $2010=1.43 \%$, RS $2011=2.22 \%$, RS $2012=$ $1.98 \%$ ), but the values were at a higher level (Fig.). Between these two periods there was a significant leap in RS ( $\triangle$ RS 2009-2010 $=+0.89 \%$ ).
RS within the period of 2007-2012 ranged from 1.53 to $2.43 \%$ (average $1.89 \%$ ).

\section{Liquidity Analysis \\ Current Liquidity/Current Ratio}

The Liquidity Analysis by the parameter Current Ratio (CR) revealed that it had an upward trend until 2009 and then a downward trend until 2012. CR fluctuated in the range from 1.65 to 2.57 (average 2.11). The value of CR in 2012 was 1.87, the second lowest value within the period studied.

\section{Quick Liquidity/Quick Ratio}

The Liquidity Analysis with the parameter Quick Ratio (QR) showed an upward trend until 2009 and then a downward trend until 2012. QR fluctuated in the range from 1.08 to 1.99 (average 1.55). The value of QR in 2012 was 1.08 , the lowest value of the period studied.

\section{Efficiency Analysis}

\section{Average Collection Period}

The Average Collection Period (ACP) within the period of 2007-2012 studied had an upward trend until 2010 and then downward trend until 2012. The ACP values ranged from 49.0 to 63.7 days (average 57.4 days), and in 2012 reached 53.8 days.

\section{Average Inventory Period}

The Average Inventory Period (AIP) fluctuated slightly over the period, since 2010 AIP has lightly risen. AIP fluctuated in the range of 28.1 to 36.5 days (average 31.6 days), and in 2012 reached a peak of 36.5 days.

\section{Average Payment Period}

The Average Payment Period (APP) was prolonged within the period of 2007-2012. In 2010 
Table 2

THE RESULTS OF PROFITABILITY, LIQUIDITY AND EFFICIENCY ANALYSIS IN 61 COMMUNITY PHARMACIES AND COMMUNITY PHARMACY BRANCHES WITHIN THE PERIOD OF 2007-2012

\begin{tabular}{|c|c|c|c|c|c|c|}
\hline Years & 2007 & 2008 & 2009 & 2010 & 2011 & 2012 \\
\hline \multicolumn{7}{|c|}{ Profitability Analysis } \\
\hline Return on Sales (\%) & 1.65 & 1.53 & 1.54 & 2.43 & 2.22 & 1.98 \\
\hline \multicolumn{7}{|c|}{ Liquidity analysis } \\
\hline Current ratio & 1.65 & 2.29 & 2.57 & 2.21 & 2.9 & 1.87 \\
\hline Quick ratio & 1.34 & 1.61 & 1.99 & 1.61 & 1.69 & 1.8 \\
\hline \multicolumn{7}{|c|}{ Efficiency Analysis } \\
\hline Average Collection Period (days) & 53.8 & 49.0 & 61.1 & 63.7 & 63.0 & 53.8 \\
\hline Average Inventory Period (days) & 30.8 & 34.7 & 29.2 & 28.1 & 30.2 & 36.5 \\
\hline Average Payment Period (days) & 79.0 & 86.1 & 89.2 & 73.7 & 81.5 & 86.3 \\
\hline
\end{tabular}

a significant jump to a lower value was recorded. Then APP was again extended. APP ranged from 73.7 to 89.2 days (average 82.6 days), and in 2012 reached the second highest value of the reporting period of 86.3 days.

Discussion. The sector of community pharmacies in the Slovak Republic underwent a dramatic change in recent years [17]. The total number of community pharmacies and community pharmacy branches increased from 965 in 2000 up to 1854 in 2011[12]. The number of pharmacies per 100000 of the population in 2007 in the Slovak Republic was almost the same as the OECD average [18]. The number of inhabitants per a community pharmacy in Europe in 2012 is given in Fig. 1.

The scientific literature research revealed the lack of data about the legal form of the ownership, the pharmacist's owner share in the capital and the limited information concerning the evaluation of the economic situation in community pharmacies.

Recently the legal form of the ownership implies a shift from the traditional way of ownership by a sole proprietor - a pharmacist (23.9\%) to legal entities, mostly the company limited (ltd) $(73.6 \%)$.

In 2002, 13 years ago, there were community pharmacies and community pharmacies branches in the Slovak Republic owned exclusively by pharmacists. Gradually the pharmacist's owner share in the capital decreased. Nowadays the owner share of a pharmacist in the capital falls to half - $50.4 \%$ in community pharmacies and $66 \%$ in community pharmacy branches, respectively.

The only publication recognized as an appropriate source that contained financial data for comparison of our results was NCPA Digest 2009. The evaluation was made by the National Community Pharmacist Association in the USA in 2008 and covered 22,728 independent community pharmacies. The financial analysis was made in a very extended form, and data were suitable for further comparison.

In 2008 Return on Sales in Slovakia was remarkably lower (1.53\%) compared to $2.7 \%$ in the USA [21]. The Current Ratio reached 1.87 and the Quick Ratio reached 1.08 contrasting to 3.6 and 1.6 in the USA. Despite all the Liquidity Ratios are within the desired range, the Quick Ratio in Slovakia is very close to the value " 1 ". In very soon time it may have shortage of money for goods purchase and without selling inventory it will not be able to ensure stocks for sale. The Average Collection Period in 2008 reached 49.0 days, the Average Inventory Period reached a peak of 34.7 days and the Average Payment Period reached a period of 86.1 days compared to 15 days, 35 days and 15 days in the USA, respectively [22]. In general, it is required to have these periods as short as it gets. A long collection period in Slovakia can lead the owners to insolvency. It is also suitable to have the shortest Average Inventory Period in order not to bind too much money in goods and prevent obsolete stock. It is also suitable to keep the Average Payment Period short to protect suppliers from insolvency.

\section{Conclusions}

Globalisation, macroeconomic development, direct and indirect regulation of pharmaceutical services resulted in changes with the unimaginable impact. Therefore, it is necessary to constantly monitor, control and evaluate the provider of pharmaceutical care, not only in terms of health, but 
also in terms of finances, at the individual level, as well as at the level of society. This can contribute to the recovery of the system and bring more added values in the field of healthcare.

\section{REFERENCES}

1. PGEU. European Community Pharmacy Blueprint. Pharmaceutical Group of European Union. 2012.

2. Eades CE, Ferguson JS, O'Carroll RE. Public health in community pharmacy: A systematic review of pharmacist and consumer views. Health \&Place. 2014;29:140-145. doi:10.1186/1471-2458-11-582

3. Rechel B, Doyle Y, Grundy E, McKee M. How can health systems respond to population ageing? WHO. 2009.

4. Anell A. Deregulating the pharmacy market: the case of Iceland and Norway. Health Policy. 2005;75(1):9-17.

5. IPU. Statement from the Irish Pharmacy Union. Irish Pharmacy Union. 2013.

6. ATKearney. The future of community pharmacy in England. ATKearney; 2012. 28 p.

7. Executive Agency for Health and Consumers (EAHC). Survey of Chain of Trust Project, under EU Public Health Programme (Grant Agreement No. 2009; 11-13).

8. Vlachynský et al. Corporate finances. Bratislava: Ekonómia; 2009.

9. Lluch M, Kanavos P. Impact of regulation of Community Pharmacies on efficiency, access and equity. Evidence from the UK and Spain. Health Policy. 2010;95(2-3):245-54. doi: 10.1016/j.healthpol.2009.11.002.

10. NCPA. 2009 NCPA Digest. National Community Pharmacist Association. 2010.

11. Grootendorst P, Rocchi M, Segal H. An Economic Analysis of the Impact of Reductions in Generic Drug Rebates on Community Pharmacy in Canada. Toronto: Leslie Dan
Faculty of Pharmacy, University of Toronto; 2008. Available from: http://individual. utoronto.ca/grootendorst/pdf/Grootendorst et_al_Pharmacy_Rebates_Report_Final.pdf.

12. Institute of Health Information and Statistics. Health Yearbook of the Slovak Republic 2000, 2007, 2008, 2009, 2010, 2011, 2012.

13. Eurostat European commission database [online] [cit. 2013-09-27]. Available from: http://epp.eurostat.ec.europa.eu/statistics explained/index.hp/Population_structure and_ageing.

14. The Trade Register of the Slovak Republic. Available from: http://www.zrsr.sk.

15. The Commercial Register of the Slovak Republic. Available from: http://www.orsr.sk.

16. The Statistical Office of the Slovak Republic. Available from: http://portal.statistics. sk/showdoc.do?docid=2213.

17. Szalay T, Pazitny P, Szalayova A, Frisova S, Morvay K, Petrovic M, Ginneken van E. Health system in Transition. Slovakia: Health system review. 2011; 13(2):203.

18. OECD. Health at a Glance 2009 OECD Indicator. Organisation for Economic Co-operation and Development; 2010.

19. Eurostat. Database number of inhabitants in 2012. Available from: http://ec.europa.eu/ eurostat $/$ tgm $/$ table.do?tab=table\&language= en\&pcode $=$ tps $00001 \&$ tableSelection $=1 \&$ footnotes=yes\&labeling=labels\&plugin $=1$

20. PGEU. Annual report 2013. Available from: http://www.pgeu.eu/en/library/224-annual-report-2013.html

21. Jackson RA. History of the digest. Available from: http://www.ncpa.co/pdf/digesthistory.pdf

22. NCPA. NCPA DIGEST 2009. Available from: http://www.ncpanet.org/pdf/digest/digest09_financials.pdf 
УДК 615.1:614.2

ИЗМЕНЕНИЯ ДЕМОГРАФИЧЕСКИХ ПОКАЗАТЕЛЕЙ, ОРГАНИЗАЦИОННО-ПРАВОВОЙ ФОРМЫ СОБСТВЕННОСТИ, ДОЛИ СОБСТВЕННОСТИ ФАРМАЦЕВТА В УСТАВНОМ КАПИТАЛЕ И ЭКОНОМИЧЕСКОЙ СИТУАЦИИ В КОММУНАЛЬНЫХ АПТЕКАХ В РЕЗУЛЬТАТЕ ГЛОБАЛИЗАЦИИ

И. Маловецка, Д. Минарикова, В. Фольтан

Целью данной работы стало определение демографической ситуации, организационно-правовой формы собственности, доли собственности фармацевта в уставном капитале и экономической ситуации в коммунальных аптеках в Словакии. Количество коммунальных (общественных) аптек постоянно увеличивается (1540 в 2012 г.). Организационно-правовые формы собственности в коммунальных аптеках представлены предприятиями с ограниченной ответственностью $(73,6 \%)$, частными предпринимателями - фармацевтами $(23,9 \%)$ и акционерными обществами (1,3\%). Сети коммунальных аптек также представлены предприятиями с ограниченной ответственностью $(73,4 \%)$, частными предпринимателями - фармацевтами $(26 \%)$, акционерными обществами (1\%). Доля собственности фармацевта в уставном капитале в коммунальных аптеках составила 50,4\%, а в сетевых коммунальных аптеках - 66\%. Финансовый анализ за период 2007-2012 гг. показал снижение рентабельности продаж (до 1,98\% в 2012 г.), уменьшение ликвидности за счет снижения коэффициента текущей ликвидности (на 1,87 в 2012 г.) и коэффициента быстрой ликвидности (на 1,08 в 2012 г.), снижение среднего периода товарооборота (до 53,8 дней в 2012 г.), незначительное увеличение среднего инвентаризационного периода (до 36,5 дней в 2012 г.) и увеличение среднего периода текущей кредиторской задолженности (86,3 дня в 2012 г.).

Ключевые слова: коммунальная аптека, демографический анализ, организационно-правовая форма поставщика фармацевтической помощи, доля собственности фармацевта в уставном капитале, финансовый анализ, прибыльность, ликвидность, эффективность.

УдК 615.1:614.2

ЗМІНИ ДЕМОГРАФІЧНИХ ПОКАЗНИКІВ, ОРГАНІЗАЦІЙНО-ПРАВОВОЇ ФОРМИ ВЛАСНОСТІ, ЧАСТКИ ВЛАСНОСТІ ФАРМАЦЕВТА У СТАТУТНОМУ КАПІТАЛІ ТА ЕКОНОМІЧНОЇ СИТУАЦІЇ У КОМУНАЛЬНИХ АПТЕКАХ У РЕЗУЛЬТАТІ ГЛОБАЛІЗАЦІЇ

І. Маловецька, Д. Мінарікова, В. Фольтан

Метою роботи стало визначення демографічної ситуації, організаційно-правової форми власності, частки власності фармацевта в статутному капіталі та економічної ситуації в комунальних аптеках у Словаччині. Кількість комунальних (громадських) аптек постійно збільшується (1540 у 2012 р). Організаційно-правові форми власності комунальних аптек представлені підприємствами з обмеженою відповідальністю (73,6\%), приватними підприємцями - фармацевтами $(23,9 \%)$ й акціонерними товариствами $(1,3 \%)$. Мережі комунальних аптек також представлені підприємствами з обмеженою відповідальністю $(73,4 \%)$, приватними підприємцями - фармацевтами (26\%), акціонерними товариствами (1\%). Частка власності фармацевта у статутному капіталі в комунальних аптеках склала 50,4\%, а в мережевих комунальних аптеках - 66\%. Фінансовий аналіз за період 2007-2012 рр. показав зниження рентабельності продажів (до 1,98\% у 2012 р.), зменшення ліквідності за рахунок зниження коефіцієнта поточної ліквідності (на 1,87 у 2012 р.) і коефіцієнта швидкої ліквідності (на 1,08 у 2012 р.), зниження середнього періоду товарообігу (до 53,8 днів у 2012 р.), незначне збільшення середнього інвентаризаційного періоду (до 36,5 днів у 2012 р.) і збільшення середнього періоду поточної кредиторської заборгованості (86,3 днів у 2012 р.).

Ключові слова: комунальна аптека, демографічний аналіз, організаційно-правова форма постачальника фармацевтичної допомоги, частка власності фармацевта у статутному капіталі, фінансовий аналіз, прибутковість, ліквідність, ефективність. 